\title{
Nigerian Economic Recession: An Islamic Perspective
}

\author{
Ali D Yusuf ${ }^{1}$ \\ Mohd Shahril Ahmad Razimi ${ }^{2}$ \\ ${ }^{1+2}$ Islamic Business School, College of Business, Universiti Utara Malaysia,Sintok 06010, Kedah, Malaysia \\ Correspondence: Ali D Yusuf, Islamic Business School, College of Business, Universiti Utara Malaysia,Sintok \\ 06010, Kedah, Malaysia, E-mail: aliyusufdanladi@gmail.com
}

Received: September 20, 2017

Accepted: September 25, 2017

Online Published: September 28, 2017

\begin{abstract}
As Nigerian economy continue to face constant economic recession, despite abundant of both natural and human resources in Nigeria due to adoption of falsehood economic system of capitalism inherent in its economic system. The major world views of economic system is on either capital or socialism which proved to be failures for centuries the only solution to the present economic predicament is Islamic economic system, which is recession proof, as it is purely based on "Adl" which is fairness and justice, social responsibility, transparency, trust worthiness, and sharia compliance.
\end{abstract}

Keywords: Recession, capitalism, socialism, Islamic, Adl.

\section{Introduction}

Nigeria has the potential to become one of the most prosperous countries in the world given its natural endowments. In addition to having the 11th largest oil reserves in the world (over 37 billion barrels), it possesses vast agricultural and water resources and has a huge and highly diversified population of over 167 million people (NBS, 2016). Despite these enormous human and material resources, Nigeria is yet to undergo the necessary structural changes that would facilitate sustainable economic development and secure acceptable minimum standard of living for its citizens (UNDP, 2014). The growth rate in major economic indicators, such as the Gross Domestic Product (GDP) and per capita income continues to be very low compared to the growth rate of the population. Capacity utilization in the manufacturing sector hovers around 48.5 percent (CBN, 2017) while inflation and unemployment remain very high. The economy is characterized by weak productive and technological bases and is highly dependent on oil (it generates over 90 percent of the country's foreign exchange earnings), which therefore makes it very vulnerable to external shocks. The return of the country to civilian administration in 1999 was marked by unprecedented euphoria from all sectors and regions of the country. In view of the widely touted positive correlation between democracy and openness on one hand, and economic growth and development on the other, this high hope cannot be said to be unrealistic. Indeed for quite a number of years, economic growth, defined strictly as a rise in GDP, did take place. After rebasing to 2010, Nigeria's GDP for 2013 was $\$ 510$ billion, making it the largest economy in Africa and the $26^{\text {th }}$ largest in the world. The problem however is that economic growth did not lead to economic development. The average growth of 6 per cent did not translate into economic development. According to the report of the National 
Bureau of Statistics (NBS, 2016) no fewer than 112 million Nigerians now live below the poverty line. This represents 67.1 percent of the country's total population. By the end of 2015, the growth of GDP has slowed down to about 2.8 percent, unemployment was about 26 per cent, inflation 9.6 per cent, lending rates averaged 25 percent and poverty incidence had widened. Nigeria's position in both the global competitiveness and the ease of doing business indices were at the very bottom among 140 countries. During the period 1999-2015, the economy depended heavily on revenues from crude oil export to finance development. Crude oil export contributed about 85 per cent of foreign exchange earnings and about the same percent of exports but contributed only about 10 percent to Gross Domestic product (GDP). Moreover the country's corruption perception index was 28\%.By the time the Buhari Administration came into power 24 months ago, the country was already moving rapidly towards stagflation. The rate of inflation rose from 9.6 per cent in 2015 to 17.9 percent in the $3^{\text {rd }}$ quarter of 2016. The extended lag in the approval and implementation of the budget coupled with the absence of clear policies to address under-consumption, infrastructure deficit and declining investment resulted in two consecutive quarters of negative GDP growth in 2016. At this juncture, the economy entered a recession. The -2.24 percent growth of GDP in the 3rdquarter and -1.30 percent in the $4^{\text {th }}$ quarter of 2016 confirmed that the economy was deeply in recession. One of the major features of economic recession is that it exposes very glaringly the existing the wealth gap in the country. This is the wide disparity between the rich and the poor as well as the over concentration of wealth in the hands of a few. While the vast majority of people are struggling for basic sustenance, a few are spending stupendous amounts in weddings and birthday parties. Within the same country also, unimaginable amounts are being recovered by the Economic and Financial Crimes Commission (EFCC) stashed away in private bank accounts, abandoned buildings and other nondescript places.

\section{Economic Recession as Product of Secular Worldview}

Economic recession is a phase in the business cycle defined as the periodic but irregular up-and-down movements in economic activity measured by fluctuations in real GDP and other macroeconomic variables like unemployment and inflation. The phases of the cycle include recovery, boom, decline and trough that repeat themselves over-time anywhere from about two to twelve years with most cycles averaging six years in length. There have been numerous recessions in the global economy since the 17 thcentury, some very serious (depressions) in the U.K., USA, Europe and developing economies like Nigeria. Some developing countries experience recessions and depressions as clients.

Now since recession is inevitable in a capitalist system, what is the alternative? What are the solutions to economic recession? To answer these questions we need to discuss the different worldviews that shape economic thoughts and generate economic systems. In doing so it is important to emphasize that we are interested in both the stability of the economic system as well its social and political ramifications. For instance some of the socio- political ramifications of the economic system of Nigeria include poverty, inequality, corruption, bad governance, crime and insecurity. Many of these ramifications are borne out of the desire to own resources.

There are basically three worldviews and philosophies within which economic systems are built. These are liberalism (whose economic system is capitalism), communism (socialism) and Islam. These three worldviews have different approaches concerning what constitutes the human economic problems as well as the solutions to these problems.

\subsection{Capitalism}

This is an economic system that is built on materialist/secular worldview. Private actors own and control 
property based on their personal interests while the forces of demand and supply freely set prices in markets. The essential feature of capitalism is the profit motive. As Adam Smith, the 18th century philosopher and father of modern economics, as cited in Paine (1995), said: "It is not from the benevolence of the butcher, the brewer, or the baker that we expect our dinner, but from their regard to their own interest." Both parties to a voluntary exchange transaction have their own interest in the outcome, but neither can obtain what he or she wants without addressing what the other wants. It is this "rational" self-interest that is expected to lead to economic prosperity through the invisible hand of laizzaiz-faire. In a capitalist economy, capital assets— such as factories, mines, and railroads - can be privately owned and controlled, labor is purchased for money wages, capital gains accrue to private owners, and prices allocate capital and labor between competing uses. The extent to which these pillars operate distinguishes various forms of capitalism. In free markets, also called laissez-faire economies, markets operate with little or no regulation. In mixed economies, so called because of the blend of markets and government, markets play a dominant role, but are regulated to a greater extent by government to correct market failures, such as pollution and traffic congestion; promote social welfare; and for other reasons, such as defense and public safety. Mixed capitalist economies pre- dominate today.

In this system the major human economic problem is as the scarcity of resources in the face of unlimited human needs. Therefore the solution to the problem is the maximization of production. If production is maximized then individuals will benefit through the "trickle-down effect". It is expected that everyone will eventually get a share of the pie. Therefore producers and entrepreneurs (capital owners) are the driving force of the economy. Hence they enjoy various types of incentives such as tax holidays. The concept of economic man is also a central feature of the system. It implies that man is materialistic and selfish by nature.

Moreover, interest is the pivot around which most economic activities revolve. The system relies on a banking system that is based on paper money with fractional reserve that is encouraged to continuously develop innovative financial products based on interest, debt and speculation. Under the capitalist economic system the net flow of money is from the poor to the rich through what is now referred to as wage slavery. Hence income inequality is a permanent feature of the system. For instance, presently, $40 \%$ of the total global asset is owned by only $1 \%$ of the population, and $50 \%$ of the population own only $1 \%$ of the global assets and finances. The pattern is the same in all capitalist countries. In the USA, $1 \%$ of the population own over $35 \%$ of all the country's wealth. In its latest report titled "Inequality in Nigeria, Exposing the Drivers", Oxfam (2016) painted an alarming picture of the Nigerian situation. It said that 112 million Nigerians are living in abject poverty. It also argued that the combined wealth of the five riches Nigerians, put at around $\$ 29.9$ billion, could end extreme poverty in the country. Other problems of capitalism include inflation (because of the ease of printing paper money), consumerism and wastage.

\subsection{Communism}

Socialism is an economic system in which there is complete absence of private ownership of property. The community owns the means of production, distribution and exchange collectively, usually through the state. It is characterized by production for use rather than profit, by equality of individual wealth, by absence of competitive economic activity, and usually by government determination of investment, process, and production levels. In socialism, the state owns the means of production, and state-owned enterprises seek to maximize social good rather than profits. Communism agrees with capitalism on the definition of the economic problem as that of scarcity emanating from limited resources and unlimited wants. So again maximization of production is seen as the solution. However, the distribution of wealth is achieved through rigid equality (all human beings are equal). The economy is centrally planned to achieve this. How much is going to be produced and who is going 
to get what and how much is determined by central command. The problem however is that the economy is complex that no matter how sophisticated the planning machinery is, it produced inefficient outcomes and created shortages.

Moreover, human beings need incentive to work and to improve their work. There has to be motivation to produce more and better. This economic system was not able to fulfill its objectives and the dreams of its philosophers were not achieved when the Soviet Union collapsed in the 1990s. Communism has virtually disappeared from the surface of the earth and only a few countries are still practicing it today. These are North Korea and, to a lesser extent, Cuba.

\section{The Islamic Economic System}

\subsection{Social responsibility (societal wellbeing)}

Themajor difference between Islamic economic system and all materialist ones is that that economic wellbeing is not viewed as the ultimate end of human life and cannot be the true purpose of life. Economic endeavors become aberrations if people are not focused on the actual purpose in their pursuit. The major difference between Islam and the other systems is existence of duality of purpose in relation to the pursuit of economic activities. Islam builds the human welfareconcept on both material and spiritual dimensions. Another important difference is Islam's view Allah has created enough resources to take care of the multifarious needs of human beings. The economic problem is therefore seen to be that of distribution of wealth and not of production. Islam makes a distinction between basic needs such as food, clothing and shelter; and luxuries. It believes that there are enough resources to satisfy the basic needs of each and every individual in the society; and to satisfy some of their wants for luxury items also. Hence the economic problem is that of distribution and not production. Under the system, man is not seen as an isolated individual but as part of a social system with an obligation to propagate what is good and discourage evil. Production is seen as a natural process that takes care of itself as long as the need exist. Islam encourages mankind to seek and develop natural resources to produce goods and services. Allah says:

"It is He who has subjugated the sea, so that you may eat fresh meat from it, and may take out from it ornaments you wear, and you see boats cleaving through it, and so that may seek His bounty and that you may be grateful" (Q16: 14)

Another unique feature of the Islamic system relates to the concept of wealth, its ownership and distribution. Wealth in Islam is not an end in itself, but a means to higher values. It should be earned, invested and spent in such a way as to benefit the individual, his family, and the society as a whole. Its benefits are enjoyed this life as well as in the hereafter. Islam recognizes the man's hunger for resources and his interest in accumulating them. The Prophet (SAW) has said:

"If the son of Adam is to be given a valley of gold, he will love to have asecond and a third, nothing fills his stomach but sand"

Islam recognizes the profit motive but adds spirituality to it. Therefore in addition to self-interest, altruism and philanthropy are important drivers of economic activity. Moreover, there is an important principle that guides economic activities in Islam; which is that all resources belong to Allah the Creator. He is the supreme owner of all wealth and human beings own resources simply as trustees. Therefore these resources are to be wisely utilized to avoid abuse, destruction and waste or idleness. This dual ownership creates checks and balances and mitigates the selfish and unfair tendencies that often result from a mistaken notion of absolute ownership.

One must stress the fact that Islam is not opposed to material pursuit or the accumulation of wealth. 
What it discourages is obsessive preoccupation with material pursuit and the accumulation of wealth at the expense of spirituality. Muslims must always strive to maintain a balance between the pursuit of this world and the hereafter. The Quran says:

"And seek (the betterment of) the ultimate abode with what Allah has given to you, and do not neglect your share from this world, and do good as Allah did good to you, and do not create mischief in the land. Sure Allah does not like mischief-makers. (Q28: 77)

\section{2 "Adl" Justice and fairness}

Islam also provides a comprehensive basis for the distribution of wealth to ensure its circulation and avoid extreme accumulation by a few individuals. It does not support the communist notion of equal distribution of wealth among individuals in the society; rather it guarantees a process of distribution where all participants in the market are rewarded for being exposed to risk and liability. Land, labour and capital jointly create value and the capital owner has to share in the profit as well as in the loss. In addition, Islam compulsorily retains a share of produced wealth through the collection of the Zakah and its disbursement to the needy; which further circulates wealth in the society. Zakah serves as a tool for poverty alleviation as well as a motivation to invest savings for the development of the economy. In addition, Muslims are encouraged to voluntary charity sadaqah and make charitable endowments (waqf) in order to create social cohesion. The unique inheritance arrangements of Islam are also designed to support the circulation of wealth.

The Islamic economic system is recession proof and resilient because it aims at circulating wealth not its concentration in the hands of a few. The distribution of wealth is achieved through the market. Islam allows the forces of demand and supply to determine prices, subject to some regulations and prohibitions. The most important of these prohibitions is that related to riba(interest). Due to its importance in relation to the issue at hand, it will be discussed at some length below.

\subsection{Shariah Compliance}

Prohibition of interest and Related Practices: Islam is extremely strict in its prohibition of interest (Riba.) Riba is an unfair, unearned, and undeserved increase in income. Riba, which is the pivot of capitalist economic system,is at the heart of most of the ills of the modern economic system.

"And whatever Riba you give so that it may increase in the wealth of the people, it does not increase with Allah" (Q30: 39).

"O you, who believe, do not consume your property among yourselves wrongfully, but let there be trade by mutual consent... (Q29: 4) "Allah has allowed (profit from) trade and prohibited Riba. So, whoever receives an advice from his Lord and stops (from taking Riba), he is allowed what has passed, and his matter is up to Allah. And the ones who revert back, those are the people of Fire. (Q2: 275-276).

In the Islamic Economic System, profit and loss sharing arrangement replaces interest. It is considered to be a fairer method of earning returns because people are rewarded in direct proportion to their investment and/or effort. The removal of interest from economic transactions creates positive indications that help to bring focus on actual entrepreneurship, trade, and production; rather than in artificial manipulations of interest rates. Indeed many of the bubbles and market crashes experienced across the globe are Interest is always inevitably associated with another prohibited element -gharar (uncertainty) through speculative activities that serve as destabilizing force on the market. Therefore institutions and individuals that are solely dedicated solely to speculation and market manipulation 
spring up everywhere. The activities of these individuals and organization disconnect the financial market from the real economy because they are not associated to projects with real-world impact and value. Practices like hoarding of capital to take advantage of higher interest rates, create distortions and instability in the market because they block capital productive activities. Hence careful financial planning is substituted by yet another prohibitive element - maysir - gambling. Hence an evil vicious circle is created that makes it impossible to predict the market.

Prohibition of interest is therefore expected to prevent speculation and gambling, which will in turn reduce instability and indebtedness. Islam does not prohibit debt, but it would be interest-free debt, managed in different financial modes that do not involve riba in any form. Many of the market crashes and financial problems in the past decades can be attributed to manipulation of interest rates and other securities, excessive speculative practices, and a lack of investment and entrepreneurship in infrastructure and new technologies. Modern economic practices also can result in unacceptable unemployment rates and infrastructure problems.

\subsection{Accountability}

In addition to riba, maysir and gharar, her prohibitions of Islam in relation to economic activities that ensure the free circulation of wealth include the prohibition of monopolies and hoarding of commodities; sale of debt; exchange of defective or worthless goods (alghish) and niggardliness. Moreover, in order to regulate inflation, Islamic economists frown at the use of paper money that is not backed with assets. Money should be used as a store of value and it should be created based on the bi-metallic system - gold and silver.

Once these prohibited elements are taken away, wealth circulates freelyand the financial system is linked to the real economy. Growth and development then ensues; and poverty and inequality are put at bay. This system worked for over 1200 years before the dissolution of the Ottoman Empire. When Muslims followed the shari'ah generally, and implement its economic system, they had a social and economic system that prosperity for all.

\subsection{Transparency and Disclosure}

Abu Ubaid provided a picture of this type of society in his famous book Al-amwaal. He recounted that during the reign of Umar (R.A.), Mu'adhbnJabal, one of the companions of the Prophet (SAW) and the governor of Yemen reported that he collected Zakah in Yemen and distributed what he could to the eligible people in Yemen there was a surplus $1 / 3$ of the proceeds. So he sent it to Sayyidina Umar (R.A.) in the capital city of Madina for him to utilize for the good of the Ummah. However, Sayyidina Umar wrote to him questioning that action, adding that 'it is not our Islamic practice to collect zakah from one part of the Muslim empire and send it to the center. You should distribute it where it was collected". Mu'adh replied "wallahiYaAmirulmu'minina I have not sent you anything for which I could find someone to give here". In the second year, Mu'adhcollected zakah, distributed it and sent two-thirds to Sayyidina Umar (RA) as surplus. The Caliph sent him the same strong message but he said he hadchecked everywhere in Yemen and could not find anyone to give Zakah. In the third year, Mu'adh collected zakahbut he could not distribute any of the proceeds in Yemen; so he sent everything to Umar (RA) stating the problem. The province of Yemen has reached the level of growth and development that had eradicated poverty and want! This is the result when the economy is built on iman, adl and the fear of Allah. 


\subsection{Honesty and trust worthiness}

This was not an isolated case. The same thing was happening all across the Muslim Empire during the reign of other Caliphs in other provinces as well.

Abu Ubaid reported another case also (bi sanadinsahih). In the days of Omar bnAbdulazeez, he appointed AbdulhamidbnAbdulrahman as the governor of Iraq. The governor sent a message to the Caliph that he had a very serious problem in his province that required urgent intervention by the Amir. He had collected Zakah and other lawful collections and had distributed to the mustahakkin (the entitled) but was not been able to exhaust it, that he still had some surplus. The Head of State, Umar bnAbdulazeez directed him to search for any citizen of Iraq that was indebted and give him to pay his debt. Under this condition no citizen should sleep with debt. The governor wrote back to say that he had actually done that before reporting the problem to the Caliph. The Amir then directed him to search for any young people (male or female) that wished to get married but did not have the means to do so and facilitate their marriage from the proceeds. "The governor said I have done that already Ya Amir-ul-Mu'minina". The Amir then asked him to search for non-Muslim citizens of the Islamic State and give them if they need.

This is the picture of an Islamic State. It is the solution to poverty and inequality as well as the prevention and cure for economic recession. Allah SWT has commanded us in his book to go back to him in order to find salvation. If we return to Allah he will provide solutions to our economic problems. "Verily this is My Way, heading straight; follow it; follow not other paths. They will scatter you away from this (great) path" (Q6: 153)

\section{Conclusion}

\subsection{Competency}

We have discussed the fact that economic recession is an inherent feature of the materialist economic system and have tried to show that the only economic system that is recession proof is the Islamic Economic System because the balance that it establishes between the worldly and spiritual pursuits as well as its in-built mechanisms that facilitate the circulation of wealth and minimizes it concentration in the hands of a few. Muslims must therefore work tireless to propagate this system. A very good starting point is to acquire the knowledge of shari'ah as it relates to fiqh-ulmu'amalat. Clearly, the type of Islamic education that most of us receive does not prepare us adequately for this. The emphasis in our schools is in ibadat (man-to-God aspects of worship) and to some extent aqidah and akhlaq. So our curricula may require an overhaul right from the basicIslamic schools. We must also go back to the original sources and dig up the knowledge of Islamic Economics from books written by scholars such as Abu

Ubaid, Abu Yusuf, Muhammad bn Hassan, IbnQayyum, IbnTaymiyya, Al-Qardawi and so on. The Rasul (SAW) has said:

"He who death overtakes while he is engaged in acquiring knowledge to a view to reviving Islam with it, there will be one degree between him andthe anbiya (prophets)"

\subsection{Iman: Strong faith}

I must say that Islamic Finance, which is an aspect of Islamic economics, is a small effort in that direction, to enable people to earn income in a halal way. Itsrecent renaissance, has already prepared the ground for us. Its global success in terms of growth and resilience is a testimony to the practicability of the Islamic economy. Today several non-Muslim countries in Europe and America are 
offering Islamic financial services. According to the World Bank,

"Islamic finance has emerged as an effective tool for financing development worldwide, including in non-Muslim countries. Major financial markets are discovering solid evidence that Islamic finance has already been mainstreamed within the global financial system - and that it has the potential to help address the challenges of ending extreme poverty and boosting shared prosperity." (World Bank, 2015) The Islamic economic system has balance approach of both materialistic and spiritual tendencies the system has been tested to recession proof, Adl, transparent, trust worthiness accountability, shariah compliance, all decision are based on maqsid shariah disclosure in transaction and openness. Islamic economic team members are competent, vast in both Islamic and the other world economic system and lot of experiences in their professional dealings. In fact Islamic economic system has "thoughtful-scholars" who are both committed and practitioners.

Indeed if we return to Allah we will find solutions to our problems!

References

Abdulrahman, A.M. and Canhan, P. (1978): The Ink of the Scholar: The Islamic Tradition of Education in Nigeria, (Macmillan, Nigeria).

Aigner, D., C.A.K. Lovell and P. Schmidt (1977): "Formulation of Frontier Production Function model", Journal of Econometrics, 6 (July): 21.

Divanna, J. and Sreth, A. (2009): A new Financial Dawn: The Rise of Islamic Finance; Leonardo and Francis; UK

Islamic Research and Training Institute (2014): Comprehensive human Development in Islam; IRTI, Jeddah

Ekpo, A. H (2013a). Promoting Inclusive Development In Nigeria: Issues of Policy Reforms And Expectations From Economic Agents, Distinguished Public Lecture, Department of Economics; University of Lagos.

Ekpo, A. H. (2017): The Nigerian Economy: Recession and Beyond; Bayero University $33^{\text {rd }}$ Convocation Lecture (Jan 2017, Kano)

Iqbal, M. (2005) (Ed.): Islamic Finance and Economic Development; Palgrave; United Kingdom

Karwai, A.K., Habib, A and Jibril, B. T (Eds.) (2012); Islamic Economics: A Book of Readings; IIIT Nigeria

Mannan, M. A. (1990); Economic Development and Social Peace in Islam; Social Peace Foundation; Bangladesh

Maududi, A.S. (1989): “The Meaning of the Qur'an", (Islamic Publication, Lahore).

Okojie, C and Shimeles (2006) "Inequality in Sub-Sharan Africa, A Synthesis of recent research on the levels, trends, effects and determinants of inequality in its different dimensions", The Inter-Regional Inequality Facility.

Oxfam (2017): http: www.Oxfam.org/en/countries/Nigeria; (Retrieved 25th May 2017)

Paine. T. (1995): Rights of Man, Common Sense and other Political Writings; Oxford University Press UNDP (Various years): Human Development Report, (Oxford University, Press).

World Bank (2015): “Global Islamic Finance Report”, (World Bank, Washington, D.C)

Okojie, C and Shimeles (2006) "Inequality in Sub-Sharan Africa, A Synthesis of recent research on the levels, trends, effects and determinants of inequality in its different dimensions", The Inter-Regional Inequality Facility.

\section{Copyrights}

Copyright for this article is retained by the author(s), with first publication rights granted to the journal. 